\title{
CAPTURING ANCIENT MURRELETS BY NIGHT-LIGHTING
}

\author{
by R. Wayne Campbell, 5536 Hardwick Street, Burnaby 2, B.C.
}

\section{Introduction}

Capturing most birds today for the purpose of banding for ecological and disitributional studies is not too difficult a task. Over the years there have evolved cannon neits and funnel traps for waterfowl, verbail-pole and balchatri traps for raptors, drop nets for shorebirds and mist nets for passerines. Few capturing devices, however, have been developed to aid the bander interested in seabirds, notably Alcids (diving seabirds such as murrelets and auks). This neglest can be attributed to various things.

Ancient Murrelets, like most true seabirds, nest in colonies on the heavily forested islands along the outer north coast of British Columbia. Rough and inhospitable littoral waters make landing on many islands hazardous and therefore inaccessible, and constant winds and dense coastal vegetations make setting up and operating traps and nets impracticable. Hence there has been little interest generated among banders in visiting seabird colonies.

The most perplexing problem in capturing Ancient Murrelets, however, is the habits of the seabirds themselves. The murrelets spend most of their lives at sea, venturing to land only during the summer months for nesting activities. During this short terrestrial visit banders must attempt to gather as much information on the birds as possible. Capturing the murrelets for banding would be simple if they nested, like gulls and terns, in open spaces. But murrelets are burrow nesters, each pair excavating a tunnel in the soft soils under tree roots, sometimes to a length of six feet. Occasionally birds can be reached in their burrows and extracted but this usually results in bent and broken feathers. Also, burrows could be shoveled out but this is too time consuming and leads to desertion by the adults and consequently is damaging to the colony.

To add further to the problems of capturing Ancient Murrelets, the birds exchange incubation duties under the cover of darkness. Seldom then are both adults together on the breeding grounds. While one parent incubates in the safety and protection of the nest chamber the mate is far at sea feeding. It is during this nocturnal flight to the colony that Ancient Murrelets can best be captured -by night-lighting.

The work covered in this paper was conducted by Norman Clarkson, Ken Kennedy, Lowel Orcutt and the writer, on southern Langara Island (Queen Charlotte Islands) in northwestern British Columbia from May 1 through May 3, 1966.

\section{Equipment}

Our equipment consisted of a single Sportsman (model no. 918) sealed power unit (six volts), two hand flashlights (three volts each), a small hand net and several burlap sacks. This apparatus is regular camping gear and is therefore simple to use and inexpensive to obtain.

\section{Procedure and Techniques}

We visited Langara Island with the intention of banding only those murrelets which could easily be extracted from their burrows. It was while visiting with a local native at camp one evening that the thought of nightlighting came to us. Sammy Davis, our Indian friend, related stories of how, in days past, his people set large fires along the beaches to attract "sea pigeons." When in range the birds, most likely Ancient Murrelets, were apparently netted and then killed. He told us that many birds flew directly into the fires. We tried this approach but used Coleman lamps instead of fires. Also, we set up mist nets in front of the lamps along the lower 
beach. For all our efforts we netted a single murrelet.

Since slope is a critical limitation for nesting Ancient Murrelets we decided to climb the nearby hills the following evening and attempt to capture the birds by night-lighting with hand lamps.

About 7:30 P.M. we could see the murrelets gathering in large rafts in the sheltered bays off shore from the colony. With fading daylight we meandered through the almost impenetrable salal underbrush following game trails to the forested slopes where the murrelets nest. We found several spots where the forest floor was devoid of vegetation and riddled with burrows. Dense tree growth must prevent sunlight from reaching these areas. We distributed our equipment, spaced ourselves about 50 feet apart, and waited. For two hours the muffled roar of the surging waters below and the gentle sounds of the wind forcing through the trees kept us company. Finally, about 10:30 P.M., the flight to the colony commenced and suddenly the air became filled with blurred, muttering forms. Soon the ground around us was alive with scampering murrelets. We watched and listened with astonishment. The birds would either crash into the sharp-needled spruce trees and fall from branch to branch, with wings flapping, to the ground, or fly directly into the large, dense salal beds. How the murrelets manage to find their respective burrows still astounds me. Finally we settled down and began night-lighting.

As soon as a bird was heard hitting the vegetation nearby an immediate search began. Once spotted the "blinded" bird was approached from the blinded side and netted. The netter then put the murrelet into a sack, to await banding. Usually six murrelets per sack was a maximum number. The flight of murrelets lasted until midnight, the peak coming about 11:00 P.M.

Most captured birds were spotted on the ground but in three instances we climbed trees, about 25 feet up, to retrieve spotted birds.

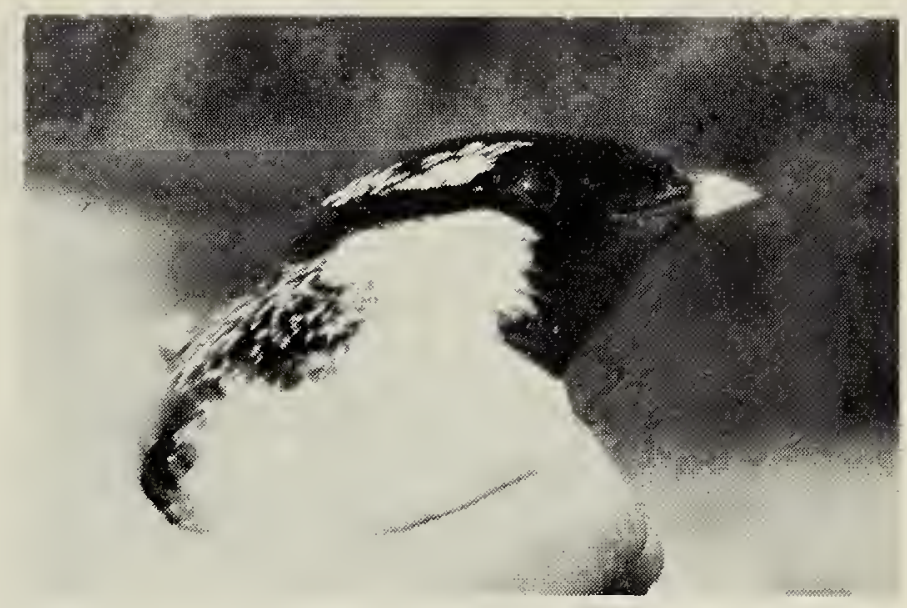

Ancient Murrelet

\section{Findings and Discussion}

Ancient Murrelets (Synthliboramphus antiquus) are quite easy to capture by night-lighting. In approximately two hours of actual operations about 30 murrelets were captured and at least another 50 were spotted but missed. We attributed our unsuccessful attempts to lack of experience and organization, weak lighting from the two smaller flashlights and the shorthandled fish net.

This preliminary attempt to capture Ancient Murrelets by nightlighting was more an experimental effort than a planned one. Just what effect, if any, night-lighting has on the murrelets is difficult to ascertain. Some birds we released went directly to their burrows, others sought protection in nearby salal bushes and some scurried to the cliff edges and flew to sea.

I feel confident that capturing seabirds by means of a strong hand lamp is the least damaging, to both bird and colony, of capturing devices used on seabirds. Hopefully, this method can be modified to increase captures and will inspire banders to look more closely at the possibility of studying seabirds.

I should also mention that I have successfully captured, though not in numbers, Leach's Petrels (Oceanodroma leucorhoa), Pigeon Guillemots (Cepphus columba), Tufted Puffins (Lunda cirrhata) and Black Turnstones (Arenaria melanocephala) by night-lighting with the Sportsman sealed power unit on other British Columbia seabird colonies. 